Louisiana State University

LSU Digital Commons

Faculty Publications

Department of Biological Sciences

$12-1-2007$

\title{
The need for proper vouchering in phylogenetic studies of birds
}

\author{
A. Townsend Peterson \\ Natural History Museum \\ Robert G. Moyle \\ Natural History Museum \\ Árpád S. Nyári \\ Natural History Museum \\ Mark B. Robbins \\ Natural History Museum \\ Robb T. Brumfield \\ Louisiana State University
}

See next page for additional authors

Follow this and additional works at: https://digitalcommons.Isu.edu/biosci_pubs

\section{Recommended Citation}

Peterson, A., Moyle, R., Nyári, Á., Robbins, M., Brumfield, R., \& Remsen, J. (2007). The need for proper vouchering in phylogenetic studies of birds. Molecular Phylogenetics and Evolution, 45 (3), 1042-1044. https://doi.org/10.1016/j.ympev.2007.08.019

This Letter to the Editor is brought to you for free and open access by the Department of Biological Sciences at LSU Digital Commons. It has been accepted for inclusion in Faculty Publications by an authorized administrator of LSU Digital Commons. For more information, please contact ir@lsu.edu. 


\section{Authors}

A. Townsend Peterson, Robert G. Moyle, Árpád S. Nyári, Mark B. Robbins, Robb T. Brumfield, and J. V. Remsen 


\section{Letter to the Editor}

\section{The need for proper vouchering in phylogenetic studies of birds}

\section{Introduction}

A recent paper published in Molecular Phylogenetics and Evolution raises an important issue in systematic biology, especially in avian systematics. Increasing numbers of avian molecular systematic studies rely on unvouchered genetic material for part or all of their sampling, a trend that we believe needs to be addressed by the systematic community. In the study that brought this issue to the forefront, Olsson et al. (2006) treated a difficult-to-identify genus of birds (Cettia) across a diverse region of South and Southeast Asia, with sampling based entirely on blood or feathers taken from 13 taxa at nine localities in China, India, Indonesia, Japan, Malaysia, Myanmar, Spain, and Vietnam. This approach is - at first glance, at least - attractive, because birds can be sampled quickly and efficiently, without the need to sacrifice the individual. Upon more careful consideration, however, sampling for phylogenetic and phylogeographic studies without full and appropriate voucher specimens deposited in publicly accessible scientific collections is both irresponsible and unconvincing, for reasons discussed below. Put simply, because phenotypic information is unavailable, we do not believe that such unvouchered studies fit the definition of "science."

\subsection{Reliance on field identifications}

Field situations are not always the best conditions under which to make difficult identifications. In our experience, a small but non-trivial proportion of specimens collected on expeditions is misidentified in the field, even by skilled field ornithologists; these errors are rectified only when vouchers are compared to museum reference collections. In particular, Old World warblers ("Sylviidae") are infamous for their complexity and identification challenges (Grimmet et al., 1999; Robson, 2000; Baker, 1997), so sampling for studies of such difficult groups should rely on a high percentage, preferably $100 \%$, of the individuals vouchered. Olsson et al. (2006), however, based sweeping conclusions - including reallocation of key populations to different species-based solely on field identifications and single samples per population. Because the individual birds sampled are no longer accessible, their study cannot be replicated (i.e., identifications based on phenotype cannot be rechecked), and therefore violates basic tenets of the scientific method.

\subsection{Systematics uses multiple character sets}

Systematics is by nature a science that relies on multiple and diverse character suites (Wiley, 1981) - species-level systematics commonly refers to evidence from plumage coloration, vocalizations, size and shape, and molecular characters gathered from series of individuals. Indeed, the long history of systematics has shown the perils of reliance on single character suites (e.g., Cracraft, 1982), a point echoed more quantitatively in molecular systematics with the realization that single gene trees may not represent population trees (Brower et al., 1996). The point, however, is more general: conclusions regarding phylogeny, relationships, and especially species limits require multiple character sets - the ability for cross-referencing among characters is critical if conclusions are to be at all robust.

The voucher-free approach followed by Olsson et al. (2006) falls into this perilous zone. For instance, among their more striking results is the polyphyly of samples attributed to Cettia flavolivacea, with samples from China and Vietnam grouping with C. vulcania - certainly, the interpretation they offer is a possibility, but other possibilities could be considered were proper vouchers prepared. First, the field identification could be correct, and certain populations of $C$. flavolivacea are in fact more closely related to C. vulcania than to other populations of C. flavolivacea: result - taxonomy must be changed. Second, the field identification could be incorrect; the individuals sampled are in fact attributable to $C$. vulcania but demonstrate a new distributional record: result - the known distribution of $C$. vulcania is revised. Third, the field identification could be incorrect and the samples represent a previously undescribed taxon: result - a new taxon needs description. These possibilities can be tested only via comparative study of the vouchers for the molecular samples with the type series of C. vulcania and C. Alavolivacea, which is not possible in the present case: distinguishing between these scenarios in the present case must await a new study with vouchered samples. Although true that additional molecular characters can likely be extracted from the blood and feather samples, the systematics community is not able to access 
information from more diverse character suites: plumage variation, morphometrics, and vocalizations are- put simply—not available for analysis. Molecular phylogenies with such limitations are problematic and cannot be verified, leaving open questions of accurate reconstruction of relationships of these organisms.

\subsection{Contribution to the scientific community}

The systematic community, and the museum community in particular, has thrived on a tradition of open exchange of material among researchers and institutions. It is hard to imagine other fields giving hard-earned data so freely to other researchers, because that is really what specimens are, in the hands of trained systematists. This system thrives when all or most of the participants not only use specimen material, but also expend the time and effort to collect new material. Although probably better than collecting no material at all, collecting unvouchered genetic samples provides little to the systematic community, and in fact sets a bad example in developing countries regarding the proper way to conduct research in phylogenetics and phylogeography. Numerous commentaries have emphasized the enormous positive contributions that specimen material makes to a broader scientific understanding of biodiversity (Peterson and Lanyon, 1992; Remsen, 1995; Winker, 1996; Winker et al., 1996; Edwards et al., 2005).

\section{Conclusions}

This letter is intended to help to improve the quality of systematic research being published by colleagues from around the world. A key feature of the scientific method is the emphasis on the potential for replication of the study and its results. Analyses based on voucher-less samples cannot be replicated because the identification and phenotypic characteristics of the individual from which the sample was obtained cannot be corroborated. Further, this type of analysis will frequently lead to erroneous results, as well as to an overly simplistic view of systematics, in which conclusions are based on too few character sets and on too narrow a base of information. Carefully prepared and preserved voucher specimens can offer vast and unanticipated additional information - for instance, migratory status can often be established based on feather shape, migratory origin can be extracted from stable isotope profiles, and misidentifications can be rectified based on plumage and morphometrics.

Of course, we understand the occasional need for representation of key taxa based on fragmentary specimen material when no other means exists for their inclusion, especially when dealing with endangered species, politically sensitive or dangerous regions, or marked individuals in ongoing population studies. Still, we see many papers based on sampling that is entirely, mostly, or partially voucher-free (Roy, 1997; Mann et al., 2006; Olsson et al., 2005, 2006), raising doubts that vouchering was really not feasible. Other studies (e.g. Cibois, 2003; Ericson et al., 2006;
Qu et al., 2006) do not distinguish between vouchered and unvouchered material: muscle tissue, blood, and feathers are listed as sources in the methods, but the sample table, if one exists, does not distinguish among the sources.

We recommend the following minimum standards in presentation of sources of molecular data: (1) repository institution name and catalog number for the voucher for each sample, (2) geographic locality from whence the sample was taken, and (3) nature of the voucher (e.g., study skin, skeleton, photograph, blood only). Although some of the concerns discussed above were addressed for mammals by Ruedas et al. (2000) and for African birds by Bates et al. (2004), the community of authors and reviewers does not appear to have noticed - or fully taken to heart - these messages. We urge our colleagues to consider carefully the implications of developing voucher-free systematic studies, and we urge editors and reviewers of molecular systematic studies to weigh these points in decisions regarding the merit of manuscripts under consideration for publication.

\section{References}

Baker, K., 1997. Warblers of Europe, Asia and North America. Princeton University Press, Princeton, New Jersey.

Bates, J.M., Bowie, R.C.K., Willard, D.E., Voelker, G., Kahindo, C., 2004. A need for continued collecting of avian voucher specimens in Africa, or: Why blood is not enough. Ostrich 75, 187-191.

Brower, A.V.Z., DeSalle, R., Vogler, A., 1996. Gene trees, species trees, and systematics: A cladistic perspective. Annual Review of Ecology and Systematics 27, 423-450.

Cibois, A., 2003. Mitochondrial DNA phylogeny of babblers (Timaliidae). Auk 120, 35-54.

Cracraft, J., 1982. Phylogenetic relationships and monophyly of loons, grebes, and hesperornithiform birds, with comments on the early history of birds. Systematic Zoology 31, 35-56.

Edwards, S.V., Birks, S., Brumfield, R.T., Hanner, R., 2005. The future of avian genetic resources collections: Archives of evolutionary and environmental history. Auk 122, 979-984.

Ericson, P.G.P., Zuccon, D., Ohlson, J.I., Johansson, U.S., Alvarenga, H., Prum, R.O., 2006. Higher-level phylogeny and morphological evolution of tyrant flycatchers, cotingas, manakins, and their allies (Aves: Tyrannida). Molecular Phylogenetics and Evolution 40, 471-483.

Grimmet, R., Inskipp, C., Inskipp, T., 1999. A Guide to the Birds of India, Pakistan, Nepal, Bangladesh, Bhutan, Sri Lanka, and the Maldives. Princeton University Press, NJ.

Mann, N.I., Barker, K.F., Graves, J., Dingess-Mann, K.A., Slater, P.J.B., 2006. Molecular data delineate four genera of "Thryothorus" wrens. Molecular Phylogenetics and Evolution 40, 750-759.

Olsson, U., Alström, P., Gelang, M., Ericson, P.G.P., Sundberg, P., 2006. Phylogeography of Indonesian and Sino-Himalayan region bush warblers (Cettia, Aves). Molecular Phylogenetics and Evolution 41, 556-565.

Olsson, U., Alström, P., Ericson, P.G.P., Sundberg, P., 2005. Nonmonophyletic taxa and cryptic species-evidence from a molecular phylogeny of leaf-warblers (Phylloscopus, Aves). Molecular Phylogenetics and Evolution 36, 261-276.

Peterson, A.T., Lanyon, S.M., 1992. New bird species, DNA studies, and type specimens: a commentary. Trends in Ecology and Evolution 7, $167-168$

Qu, Y., Ericson, P.G.P., Lei, F., Gebauer, A., Kaiser, M., Helbig, A.J., 2006. Molecular phylogenetic relationship of the snow finch complex (genera Montifringilla, Pyrgilauda, and Onychostruthus) from the Tibetan plateau. Molecular Phylogenetics and Evolution 40, 218-226. 
Remsen, J.V., 1995. The importance of continued collecting of bird specimens to ornithology and bird conservation. Bird Conservation International 5, 145-180.

Robson, C., 2000. A Guide to the Birds of Southeast Asia. Princeton University Press, NJ.

Roy, M.S., 1997. Recent diversification in African greenbuls (Andropadus) supports a montane speciation model. Proceedings of the Royal Society of London B 264, 1337-1344.

Ruedas, L.A., Salazar-Bravo, J., Dragoo, J.W., Yates, T.L., 2000. The importance of being earnest: what, if anything, constitutes a "specimen examined?". Molecular Phylogenetics and Evolution 17, 129-132.

Wiley, E.O., 1981. Phylogenetics. John Wiley \& Sons, New York.

Winker, K., 1996. The crumbling infrastucture of biodiversity: the avian example. Conservation Biology 10, 703-707.

Winker, K., Braun, M.J., Graves, G.R., 1996. Voucher specimens and quality control in avian molecular studies. Ibis 138, 345-347.

\section{A. Townsend Peterson *}

Robert G. Moyle

Árpád S. Nyári

Mark B. Robbins

Natural History Museum, Biodiversity Research Center, and

Department of Ecology and Evolutionary Biology,

University of Kansas, Dyche Hall, Lawrence, KS, 66045, USA

E-mail address: town@ku.edu (A.T. Peterson)

Robb T. Brumfield

J.V. Remsen Jr.

Museum of Natural Science and Department of

Biological Sciences, Louisiana State University,

Baton Rouge, LA, 70803, USA

Received 20 March 2007; revised 28 August 2007; accepted for publication 30 August 2007

Available online 18 September 2007 